\title{
ECONOMIC EVALUATION OF CULTIVATION AND FINALIZATION OF THE PRODUCTS FROM THE SEA BUCKTHORN
}

\section{Lubomír Gurčik* , Viktor Porhajaš, Dávid Červený, Zuzana Bajusová}

Slovak University of Agriculture in Nitra, Slovak Republic

\begin{abstract}
The paper discusses economic evaluation of the sea buckthorn cultivation as well as production of final products by processing the fruits of this economically interesting woody plant. The input data of the economic "ex post" analysis is based on the authentic data of the agricultural entity operating in Slovakia. Recently, we have been expanding the growing area of sea buckthorn to which we are contributing by educating and promoting the products from this medicinal plant. Sea buckthorn is an extraordinary healing plant called the "lemon tree of the north". One sea buckthorn fruit will cover the daily dose of vitamin C. Even the ancient Greeks knew about the effects of sea buckthorn, which formed the basis for its Latin name - Hippophae rhamnoides - which means a shining horse. The sea buckthorn's name was associated with a beautiful shiny coat of horses grazing on the plant. It is one of the world's most nutrient-rich plants because sea buckthorn areas have a unique composition and chemical analyses have confirmed that more than 190 substances are the best-ever independent source of natural clustering. These substances contain 10 different vitamins, 18 amino acids, 24 minerals and trace elements. Sea buckthorn has a high content of mono and polyunsaturated essential acids (omega 3, 6, 7 and 9) and phytosterols. It contains vitamins C, E, beta-carotene and another 40 carotenoids. The fruits contain all $B$ vitamins. For these reasons, we consider buckthorn to be an exceptional plant that has the potential to expand its cultivation in all production areas. In the SR, the cultivation of sea buckthorn is based on small gardeners, on larger areas; the cultivation of this healing plant is a unique matter. An advertising campaign that promotes sea buckthron products has been launched by the pharmaceutical industry and its distribution networks. This increased interest creates a precondition for the expansion of the cultivation in the Slovak Republic.
\end{abstract}

Keywords: sea buckthorn, production costs, sales, profit, product analysis

\section{Introduction}

The sea buckthorn is considered a functional, even healing food. It is characterized not only by its nutritional value but also by its beneficial effects on the health of its consumer. Its consumption protects consumers against illnesses, slows down the aging process and strengthens the defences against external influences. Sea buckthorn, as a functional food, is not one of the drugs, but it is an intermediate step between common foods and medicines. It positively affects the human body in the transition period between health and disease (Zeb, 2004).

Sea buckthorn shows antiviral activity against influenza virus, increases resistance to herpes simplex, cytomegalovirus and adenovirus and also inhibits HIV infections in cells.

It has been shown that sea buckthorn consumption controls high blood pressure, heart rate, lowers total cholesterol and triglycerides in blood serum, increases HDL cholesterol, and reduces oxidative susceptibility of LDL cholesterol. The combination of polyunsaturated fatty acids and polyphenols suppresses platelet aggregation and thus prevents thrombosis (Ciesarová, Benčičová, 2017). When setting up a sea buckthorn plantation, we must place great emphasis on the selection of the land suitable for growing it. Unsuitable soils, according to Bajer (2014), are moist for a long time, which does not allow the sea buckthorn to achieve the required parameters in achieving the crop and its quality. For the sake of better fertility, the plantations of sea buckthorn are recommended to be established in the fall - to catch the winter's warmth, a rapid onset of growth. We should plan to plant sea buckthorn in spring only if the soil and climatic conditions did not allow us to plant in autumn. Before setting up the sea buckthorn plantation, it is necessary to plow the soil to a depth of 300-500 mm, and fertilize with 150-180 kg/ha of potassium and $200-250 \mathrm{~kg} / \mathrm{ha}$ of phosphate fertilizer.

An essential condition is also the adjustment of the soil pH by liming, whereby the surfaces cannot be wet. Prior to planting, an organic fertilizer is applied. For economic reasons, we prefer manure. Young plants will be supported by spring fertilization. The recommended dose of nitrogen per hectare is $40-60 \mathrm{~kg}, 80-100 \mathrm{~kg}$ of phosphate fertilizers, $60-90 \mathrm{~kg}$ of potassium fertilizers. These relatively high doses of nutrients are essential especially during the first four years. Sea buckthorn thrives best in soils that contain humus, potassium, phosphorus, and lack of soil moisture. Optimal conditions consist of soil pH 6.5-7, with phosphorus content of 10-50 mg/100 kg, potassium $250 \mathrm{mg}$, calcium $1000 \mathrm{mg}$, magnesium $100 \mathrm{mg}$ with the soil moisture 65-70\% (Bajer, 2014). The harvest is low due to very acidic soils ( 3 to $4 \mathrm{pH}$ ) and it is not recommended to grow sea buckthorn in such soils. It does not succeed in heavy aluminum-clay, salted and sandy soils, or in soils with high groundwater (Valíček and Havelka, 2008).

\section{Material and methods}

The aim of the paper is to economically evaluate the cultivation and finalization of sea buckthorn products. The background data are authentic data from a farm operating in western Slovakia and cultivating sea buckthorn in the area of 12.5 ha. We focused the economic analysis on the indicators that have a meaningful value for us. The paper deals with the possibilities of sea buckthorn product finalization. The work includes a proposal for the establishment of a small farm for the cultivation of sea buckthorn. We will use economic efficiency indicators in the work.

Profitability indicators used:

1. Profit/loss from final production $=$ revenues - full own cost per $1 \mathrm{~kg} \times$ realized amount in $\mathrm{kg}$

2. Final production revenue $=$ final product price for $1 \mathrm{~kg} \times$ production in $\mathrm{kg}$

3. Return on costs in $\%=$ profit before tax/full own cost $\times 100$

4. Return on Sales in $\%=$ Pre-tax Profit/Sales $\times 100$ 


\section{Results and discussion}

\section{Technical-technological principles of plantation establishment}

The quality of the seedlings and the preparation of the soil are important for a planting stock.

Woody age: $2-3$ years

Main root length: $0.20 \mathrm{~m}$

Number of main roots: $3-5$ pcs

Plant height: $0.35-0.5 \mathrm{~m}$

Diameter of the root: $6-8 \mathrm{~mm}$

Number of lateral shoots: 3-5 (Paprštejn et al., 2009).

Sea buckthorn has specific requirements for planting stock. These demands are also due to the fact that it is a demi-plant that is pollinated by the wind. Therefore, male and female seedlings should be planted separately. The ratio of male females pollinating is $1: 6(1: 8)$, with plantations it is appropriate to keep the ratio of $1: 9(1: 10)$. Plants are planted in a buckle of $4 \times 1.5$ to $2 \mathrm{~m}$ (Paprštein et al., 2009). Good production results have been reported in practice when male plants were in every third row, with each third plant in this series being male. It is also appropriate to plant different male varieties for different female varieties. The reason for this requirement is to prolong the pollination time and thereby increase the pollination success rate by pollen of male plants flowering in a different time period.

In the treatment of sea buckthorn, an educational and maintenance cut is performed. The educational cut is performed in the spring, just after the autumn planting, when the shoots of plants are shortened by two thirds. During the following years, we perform the maintenance cuts. This is especially important for the shining of the bush (Hričovský et al., 2000).

The incidence of morbidity is heavily dependent on the inadequacy of plantation land selection, including inappropriate soil and climatic conditions. As a rule, it is reflected in the yellowing of the plants. It is a consequence of fungal infestation, in particular fetal endomycosis, fuzariosis wilt, buckthorn scab, and so on. The most common pests of sea buckthorns are sea buckthorn aphids, sea buckthorn moths, sea buckthorn flies and many others (Valíček and Havelka, 2008).

The advantage of sea buckthorn cultivation is that it grows fast and the plants are born in the third, but also in the sixth year after planting. It depends not only on the variety, but also on the technology of cultivation, which is related to the quality of the seed material, nutrition, irrigation and so on. This fact is confirmed by the authors dealing with the cultivation of small fruits (Gurčik, Porhajaš and Bajusová, 2017). If the sea buckthorn is propagated by seeds and not vegetative cuttings, the plants will bear only a quarter of the fruit in the fourth year. They usually bear fruit in the fifth year (Bajer, 2014). Adult individuals grow to a height of up to $6 \mathrm{~m}$. Harvesting is quite challenging. The most commonly used technique is twig cutting with subsequent freezing of the fruit. This method originated in the conditions of Siberia, where the fruits froze on trees then they were shaken into sails spreading under the bushes (Valíček and Havelka, 2008). Sea buckthorn yields every year, but the crop is significantly higher every other year. This is because harvesting crops are fruiting shoots (about 30\% of the plant) and they are regenerated in the coming year. More radically, its growth and harvest cycle can be fundamentally affected. Another way of harvesting, which is now used to a lesser extent, is the so-called "milking". This harvest uses special tongs and a wooden container, into which the juice flows and the berries fall. This container must not be made of metal in order not to damage the juice (Hensel, 2007).

We collect sea buckthorn berries from August to October, depending on the variety. It is advisable to realize the harvesting before full maturity in order to maintain the quality of the fruits and consequently the products produced from them. Paprštein et al. (2009) report that production from one plant ranges from 14 to $20 \mathrm{~kg}$. At 1250 individuals per hectare, by a yield of $20 \mathrm{~kg}$ from one plant, it can be reported that a hectare yields 25 tons (every other year, i.e. 12.5 tons per year and hectare).

The average harvest in the plantation under reviewing in the first five years of its birth rate ranged from 2.2 to $5.8 \mathrm{~kg}$ per individual, depending on weather conditions. Harvesting was done by cutting twigs and freezing up to $-18{ }^{\circ} \mathrm{C}$. Such frozen fruits are easily mechanically (by shaking) separated from the twigs. The average annual yield per shrub was from 1.1 to $2.9 \mathrm{~kg}$, i.e. on average from 1.45 to $3.6 \mathrm{t}$ per hectare per year. These productioncharacterizing results are significantly lower than those in the literature. The reasons for this were mainly the underestimation of the choice of variety, the unavailability of seed material in the required quality and quantity, but also the inappropriate decision on planting area, which suffers from a lack of water for irrigation purposes. Our company has finalized our production in the form of extract, syrup, oil and tea.

Our plantation of sea buckthorn was established in 2008 in autumn, on an area of $12.5 \mathrm{ha}$. The first fertile year of the plantation was the fourth year after planting, i.e. 2012. The monitored costs and production indicators were reported for the period from 2012 to 2016.

As reported in the Table 1 and 2, the production of sea buckthorn grew during the reference period. In the second production year, compared to the first production year, it increased by $13.6 \%$. The highest production growth was recorded in the third production year, up to 52\%. In 2015 and 2016, the growth output index oscillated around 1.23. Production costs also increased during the period under review (Gurčík et al., 2012). However, their dynamics lagged behind the pace of production. If the production of the first five years of sea buckthorn grew by $28.2 \%$ on average, the average increase in production costs was $23.8 \%$. This was also positively reflected in the performance results.

As we have already mentioned, the entire production of sea buckthorn is processed into final products on the farm. In Tables 1 and 2, we simulated

Table 1 Sea buckthorn production, costs, sales and profitability of production for 2012 to 2016

\begin{tabular}{|c|c|c|c|c|c|c|}
\hline Year & Production in kg & Total costs in EUR & Sales in EUR & Profit in EUR & Return on costs in $\%$ & Return on sales in \% \\
\hline 2012 & 95,624 & 34,375 & 103,125 & 7,501 & 7.84 & 7.27 \\
\hline 2013 & 100,328 & 39,063 & 117,188 & 16,859 & 16.80 & 14.39 \\
\hline 2014 & 120,714 & 59,375 & 178,125 & 57,411 & 47.56 & 32.23 \\
\hline 2015 & 134,827 & 73,438 & 220,313 & 85,486 & 63.40 & 38.80 \\
\hline
\end{tabular}

Source: Company statements, own processing 
Table 2 Production per hectare, costs, revenues and profit/loss in the cultivation of sea buckthorn

\begin{tabular}{|c|c|c|c|c|c|c|c|c|c|}
\hline \multirow[t]{3}{*}{ Year } & \multirow{2}{*}{\multicolumn{2}{|c|}{ Average yield in kg }} & \multicolumn{5}{|c|}{ Costs per hectare in EUR } & \multirow{3}{*}{$\begin{array}{c}\text { Sales per } \\
\text { hectare in EUR }\end{array}$} & \multirow{3}{*}{$\begin{array}{c}\text { Profit per } \\
\text { hectare in EUR }\end{array}$} \\
\hline & & & \multicolumn{2}{|c|}{ variable costs } & \multicolumn{2}{|c|}{ fixed costs } & \multirow{2}{*}{$\begin{array}{l}\text { total } \\
\text { costs }\end{array}$} & & \\
\hline & perha & per plant & production consumption & personal cots & depreciation & others & & & \\
\hline 2012 & 2,750 & 2.20 & 715 & 2,045 & 1740 & 3,150 & 7,650 & 8,250 & 600 \\
\hline 2013 & 3,125 & 2.50 & 813 & 2,324 & 1740 & 3,150 & 8,026 & 9,375 & 1,349 \\
\hline 2014 & 4,750 & 3.80 & 1,235 & 3,532 & 1740 & 3,150 & 9,657 & 14,250 & 4,593 \\
\hline 2015 & 5,875 & 4.70 & 1,528 & 4,369 & 1740 & 3,150 & 10,786 & 17,625 & 6,839 \\
\hline 2016 & 7,250 & 5.80 & 1,885 & 5,391 & 1740 & 3,150 & 12,166 & 21,750 & 9,584 \\
\hline Expected average annual yield & 18,750 & 15.00 & 4,875 & 13,943 & 1740 & 3,150 & 23,708 & 56,250 & 32,542 \\
\hline
\end{tabular}

Source: Company statements, own processing

a situation where the farm would sell its entire sea buckthorn frozen. With a projected volume of plantation production and, at the same time, a lack of storage capacity, the farm would be in a weak position to negotiate sales conditions. That is why the likely cost of production is projected at 3.00 EUR per kilogram. This is a premise ensuring sales in the first production year of 12.5 hectares of plantations at 103,125 EUR. Under these conditions, sales in 2016 would amount to 271,875 EUR, which is 2.64 times more than in the first growing year of the plantation. Return on costs in 2012 was $7.8 \%$. Return on sales in the given year was $7.3 \%$. The difference between cost-effectiveness and return on sales was still growing. In 2016, the return on sales was $44.1 \%$ and the return on production costs was $78.8 \%$.

For the linearly evolving variable costs and stable fixed costs per hectare of plantation, the contribution to pay for fixed costs (profit generation) of 1 $\mathrm{kg}$ of grown and sold sea buckthorn fruits would be 2 EUR. This means that for the production of $2,450 \mathrm{~kg}$ per hectare, a zero profit would be achieved (Porhajaš and Gurčíková, 2016).
The projected earnings per hectare of plantation, for the period from 2012 to 2016, range from 600 EUR to 9,584 EUR. If plantation crops were expected to be at an average of $15 \mathrm{~kg}$ per plant, the profit of 1 hectare would be at a level exceeding 30,000 EUR. When comparing the economic results of cultivation of conventional crops such as cereals, root crops and oilseeds, the profit in the cultivation of sea buckthorn is achieved despite the fact that building a plantation requires considerable investment.

For the partial analysis of economic efficiency indicators, we have selected the final products made from our own sea buckthorn crop, which are decisive determinants of revenue generation (more than $80 \%$ of their annual volume). As shown in Table 3, sales for the period under review were gradually increasing. In 2014, they amounted to 936,260 EUR, which was $19.8 \%$ more than in 2015. A lower profit in 2015 was achieved despite the fact that the harvest was almost $24 \%$ higher in the current marketing year. This was due to higher product prices.

Table 3 Production, average realization prices and sales of selected final sea buckthorn products

\begin{tabular}{|c|c|c|c|c|c|c|c|c|c|c|}
\hline \multirow[t]{2}{*}{ Final products } & \multicolumn{4}{|c|}{ Production in natural expression } & \multicolumn{3}{|c|}{ Average realization prices in EUR } & \multicolumn{3}{|c|}{ Sales in EUR } \\
\hline & MU & 2014 & 2015 & 2016 & 2014 & 2015 & 2016 & 2014 & 2015 & 2016 \\
\hline $100 \%$ sea buckthorn extract $200 \mathrm{ml}$ & lit. & 9,292 & 13,263 & 16,412 & 39.55 & 19.80 & 26.15 & 367,499 & 262,607 & 429,174 \\
\hline $100 \%$ BlO oil & pc. & 10,342 & 12,057 & 14,920 & 23.80 & 20.10 & 18.10 & 246,140 & 242,346 & 270,052 \\
\hline $100 \%$ sea buckthorn syrup $250 \mathrm{ml}$ & pc. & 29,650 & 20,669 & 25,578 & 4.95 & 3.30 & 3.70 & 146,768 & 68,208 & 94,639 \\
\hline Frozen sea buckthorn & pc. & 4,934 & 9,186 & 11,368 & 6.00 & 3.00 & 2.40 & 29,604 & 27,558 & 27,283 \\
\hline \multirow[t]{2}{*}{$100 \%$ loose B10 tea $50 \mathrm{~g}$} & pc. & 56,250 & 72,343 & 87,047 & 2.60 & 2.50 & 2.70 & 146,250 & 180,858 & 235,027 \\
\hline & & & & & & & & 936,260 & 781,576 & $1,056,175$ \\
\hline
\end{tabular}

Source: Company statements, own processing

Table 4 Production costs, profit and cost-effectiveness of selected final sea buckthorn products

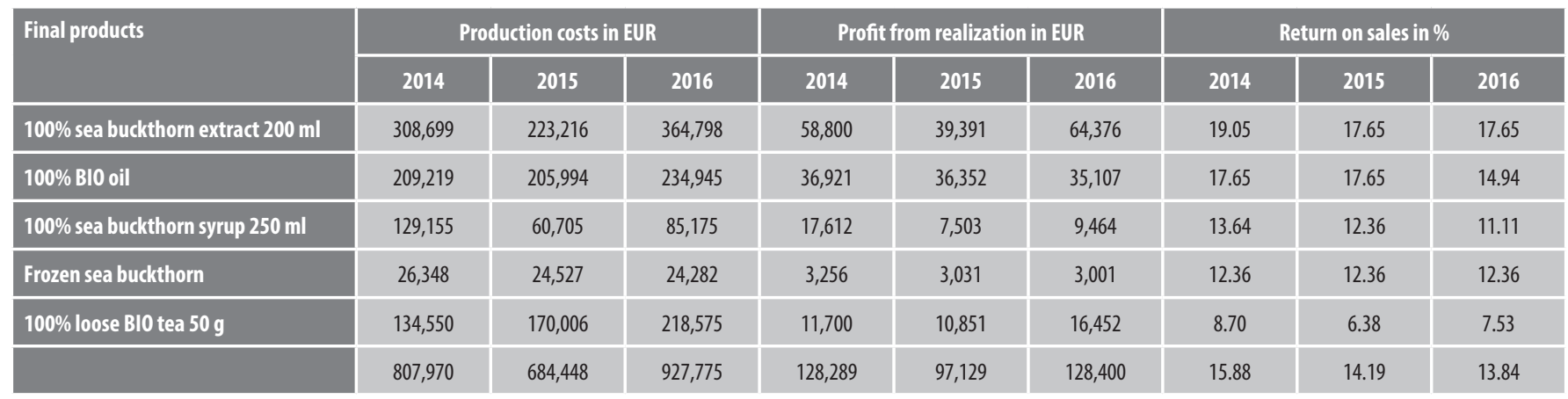

Source: Company statements, own processing 
Table 4 shows that the total profit from the production of the selected range of final products is stagnating. In 2014 and 2016, it oscillates at around 128000 EUR. Profit stagnation is reported despite the fact that sales in 2016 increased by almost $12.8 \%$ compared to 2014. This is also explained by the downward trend in return on sales for all final products, which fell from $15.88 \%$ to $13.84 \%$. The highest return on sales was achieved in the implementation of 100\% extract in $200 \mathrm{ml}$ packaging in 2014 (19.05\%). Although the profitability of this product decreases from year to year, it has retained its highest value throughout the reporting period from 2014 to 2016.

The plantation is a cultivation of completely permanent crops with a fertility time of more than three years, the investment costs for setting up the orchard will be reflected in operating costs in the form of depreciation. In particular, in authentic farm conditions, the plantation is depreciated by a uniform - linear depreciation. Manufacturing companies have not been provided with data that would make it possible to assess more objectively the economic efficiency of the investment in fixed assets, including net present value, internal rate of return and payback period. We are convinced that the data presented by our contribution and the resulting indicators of economic efficiency of production will be of benefit to those researchers as well as practitioners dealing with the issue. The presented data is not normally available to the professional and practical community. The dynamic character of the indicators presented by us was that fixed costs represented by depreciation of fixed assets, which is absolutely necessary to ensure the production of sea buckthorn as well as products produced from its fruits, are part of production costs.

The anticipated expenditure for the establishment of one hectare of sea buckthorn plantation, including irrigation, was 16,100 EUR in our subject. Establishing irrigation is a limiting factor in achieving a good harvest of sea buckthorn. Of the total amount of 16,100 EUR, they represent 4,000 EUR, representing almost one quarter of total investment.

\section{Conclusion}

The economic evaluation of the cultivation of sea buckthorn was based on authentic documentation of a specific farm operating in Slovakia. In this paper, we evaluated basic economic indicators such as revenues, costs, profit, as well as selected ratio indicators of economic efficiency for the period of 2012-2016. Profit from a hectare of plantation for the period from 2012 to 2016 varies from 600 to 9,584 EUR, depending on production and production price. It is assumed that, at the time of full plantation production, an average yield of $15 \mathrm{~kg}$ per plant will be achieved, and it is realistic that a profit of 1 hectare will be at a level of above 30,000 EUR. When compared to the economic results of cultivation of conventional crops such as cereals, root crops and oilseeds, the profit in the cultivation of sea buckthorn is achieved despite the fact that building a plantation requires considerable investment.

The economic effect can also be increased by the finalization of sea buckthorn berries under farm conditions. Return on sales of these final products ranged from 6.38 to $19.05 \%$ over the period under review.

\section{References}

BAJER, J. 2014. Rakytník, zázračná rostlina, oranžový poklad. Mladá Fronta, 2014, 160 p. ISBN 978-80-204-3385-5.

CIESAROVÁ, Z. - BENČIČOVÁ, M. 2017. Č́m je výnimočný rakytník rešetliakový?. In Trendy v potravinárstve, vol. 22, 2017, no. 2, pp. 96 - 100. ISSN 1336 - 085X.

HENSEL, W. 2007. Poznáváme léčivé rostliny v naší prírodě. Praha : Beta - Dobrovský, 2007, 125 p. ISBN 978-80-7306-270-5.

GURČÍK, L. - ADAMIČKOVÁ, I. - PORHAJAŠ, V. - TURČEKOVÁ, N. Metodologické aspekty hodnotenia ekonomickej efektívnosti výroby ovocia $\mathrm{v}$ podmienkach Slovenskej republiky. $1^{\text {st }}$ ed., Nitra : SPU, 2012, 230 p. ISBN 978-80-552-0925-8.

GURČ́́K, L. - PORHAJAŠ, V. - BAJUSOVÁ, Z. 2017. Economic aspects of black chokeberry grown in marginal areas in Slovakia. Agrarian perspectives, Praha : Czech University of Life Sciences, 2017, p. 88-94. ISBN 978-80-213-2787-0.

HRIČOVSKÝ, I. a i. 2000. Pomológia. SR: Nezávislost', 2000. 360 p. ISBN 80-85217-64-3.

PAPRŠTEIN, F. a i. 2009. Technologie pěstování a množení rakytníku rešetlákového (Hippophae rhamnoides L./.ČR: Výzkumný a šlechtitel'ský ústav ovocinářský Holovousy S. r. . ., 2009, 29 p. ISBN 978-80-87030-07-3.

PORHAJAŠ, V. - GURČ́KOVVÁ, K. Zadlženost' ako determinant prosperity podniku : monografia. Praha : Wolters Kluwer ČR, 2016, 95 p. ISBN 978-80-7552-177-4.

VALIIČEK, P. - HAVELKA, E. 2008. Rakytník rešetlákový - rostlina budoucnosti. Benešov : Start, 2008, 88 p. ISBN 978-80-86231-44-0.

ZEB, A. 2004. Important therapeutic uses of Sea Buckthorn (Hippophae): A review. In Journal of biological sciences, vol. 4, 2004, no. 6, pp. 687-693. ISSN 1727 - 3048.

\section{Contact address}

Lubomír Gurčík, Slovak University of Agriculture in Nitra, Faculty of Economics and Management, Tr. Andreja Hlinku 2, 94976 Nitra, Slovak Republic, e-mail: lubomir.gurcik@uniag.sk 